Course Enhancement by Melding the BOK2 Student Outcomes with the Project Management Body of Knowledge

Prof. John V Tocco JD, Lawrence Technological University 


\title{
Course Enhancement by Melding the BOK2 Student Outcomes with the Project Management Body of Knowledge
}

\begin{abstract}
The Civil Engineering Body of Knowledge, Second Edition (BOK2), promulgated by the American Society of Civil Engineering, defines twenty-four student outcomes for civil engineering programs. The inclusion of outcome 13 Project Management was a tacit acknowledgement that construction engineering and project management skills were important components of a broad civil engineering education. When the BOK2 was adopted by the Civil Engineering program at Lawrence Technological University, faculty recognized that outcome 13 required the elevation of Civil Engineering Management Practices (CE Management), the lynchpin course for construction engineering, from an elective to a required course. While several outcomes are addressed in the course, the core outcome is No. 13 Project Management. Moreover, by way of providing additional depth on how to satisfy the outcome, the BOK2 cites the Project Management Body of Knowledge, published by the Project Management Institute and currently in its fifth edition (PMBOK5), as an authority on project management principles. With the dual goals of enhancing the course and addressing the BOK2 more directly, the CE Management instructor adopted a framework based on the five project management processes as set forth in PMBOK5. The initial purpose of this paper is to discuss the BOK2 student outcomes CE Management was required to cover, based on faculty discussions as to overall program needs. Next addressed is the mapping of and interaction among the PMBOK5 knowledge areas and the outcomes. The paper also describes the various pedagogical elements utilized to deliver course content. For example, online lectures in combination with in-class discussions were utilized in a "flipping" strategy, enabling a more thoughtful interaction with students. The instructor also developed and utilized several formal and informal problem based learning and active collaborative learning practicums with oral and written components, many of which were assessed using detailed rubrics.
\end{abstract}

\section{Introduction}

\section{A. Civil Engineering Program}

Lawrence Technological University (Lawrence Tech) is a private school located in Southfield, Michigan, a suburb of Detroit. Converted from a construction engineering program, the Civil Engineering program earned its initial ABET accreditation in 1993. The most recent accreditation evaluation occurred in 2010, with the program earning the full six-year cycle. There are approximately 120 undergraduate students, and the program employs seven full-time faculty members, with approximately ten adjuncts. The curriculum covers six civil engineering subdisciplines: transportation, water resources, environmental, structural, geotechnical, and construction engineering.

To graduate, students are required to pass at least one course in each of the recognized civil engineering subdisciplines. Students may then specialize in one or more of the subdisciplines by 
enrolling in several available electives. To complete their education, undergraduates participate in a two-course capstone design and project management sequence during their senior year.

\section{B. Foundation for the Civil Engineering Body of Knowledge Second Edition}

Policy Statement 465 Academic Prerequisites for Licensure and Professional Practice $e^{1}$ (PSA 465), initially published in 1998 and updated several times, was a clarion call by the American Society of Civil Engineers (ASCE) for the creation of an industry body of knowledge (BOK). According to PSA 465, a BOK would describe the necessary depth and breadth of knowledge and skills required of an individual to become a competent civil engineering practitioner. In furtherance of the mission, the BOK would also address the requirements for a baccalaureate degree in civil engineering.

In 2007, the ASCE published The Vision for Civil Engineering in $2025^{2}$ (Vision), a document based on discussions held at a summit of civil engineers and other industry and government leaders. The various positions of civil engineers as professionals were encapsulated in the Vision, such as serving as master constructor and as a steward of the natural environment.

The initial BOK created by the ASCE was considered a work in progress and, in tandem with the Vision, formed the foundation for the Civil Engineering Body of Knowledge for the $21^{\text {st }}$ Century, Preparing the Civil Engineer for the Future, Second Edition ${ }^{3}$ (BOK2). The signature accomplishment of the BOK2 is the articulation of the twenty-four outcomes necessary for fulfilling the body of knowledge; i.e., the skills a person must master to become a professional civil engineer. The BOK2 outcomes are set forth in Figure 1.

\begin{tabular}{|c|l|}
\hline No. & \multicolumn{1}{|c|}{ Outcome } \\
\hline 1 & Mathematics \\
\hline 2 & Natural Sciences \\
\hline 3 & Humanities \\
\hline 4 & Social Sciences \\
\hline 5 & Materials Science \\
\hline 6 & Mechanics \\
\hline 7 & Experiments \\
\hline 8 & $\begin{array}{l}\text { Problem Recognition and } \\
\text { Solving }\end{array}$ \\
\hline 9 & Design \\
\hline 10 & Sustainability \\
\hline 11 & $\begin{array}{l}\text { Contemporary Issues and } \\
\text { Historical Perspectives }\end{array}$ \\
\hline 12 & Risk and Uncertainty \\
\hline
\end{tabular}

\begin{tabular}{|c|l|}
\hline No. & \multicolumn{1}{|c|}{ Outcome } \\
\hline 13 & Project Management \\
\hline 14 & $\begin{array}{l}\text { Breadth in Civil Engineering } \\
\text { Areas }\end{array}$ \\
\hline 15 & Technical Specialization \\
\hline 16 & Communication \\
\hline 17 & Public Policy \\
\hline 18 & $\begin{array}{l}\text { Business and Public } \\
\text { Administration }\end{array}$ \\
\hline 19 & Globalization \\
\hline 20 & Leadership \\
\hline 21 & Teamwork \\
\hline 22 & Attitudes \\
\hline 23 & Lifelong Learning \\
\hline 24 & $\begin{array}{l}\text { Professional and Ethical } \\
\text { Responsibility }\end{array}$ \\
\hline
\end{tabular}

Figure 1: BOK2 Outcomes 
Although the BOK2 was developed based on input from numerous civil engineering professionals and academics, the outcome language was strongly influenced by the ABET Criteria for Accrediting Engineering Programs ${ }^{4}$, which includes the standard ABET a-k student outcomes and the Program Criteria for Civil and Similarly Named Engineering Programs. ${ }^{5}$ The BOK2 includes tables that map its outcomes to the standard ABET outcomes.

In 2009 the Lawrence Tech Civil Engineering program adopted the BOK2 for the foundation of its student outcomes, and in 2010 the program earned re-accreditation by ABET for the full six years. The BOK2 student outcomes, along with their descriptions developed by faculty, are attached as Appendix A.

It is interesting to note that the ABET a-k outcomes do not include a direct reference to project management, nor is management addressed tangentially. By requiring a project management outcome, the BOK2 explicitly acknowledges the importance of civil engineering students developing the ability to apply project management concepts in their professional endeavors.

\section{Overview of the Project Management Body of Knowledge Fifth Edition}

The Project Management Institute ${ }^{6}$ (PMI) is a worldwide, non-profit association that, among other things, creates project management standards, certifies project management professionals, and sponsors research and continuing education. PMI has published project management standards since the 1980s, and the most recent standard is included in A Guide to the Project Management Body of Knowledge, Fifth Edition?(PMBOK5).

The PMBOK5 is a general project management standard that has wide applicability. Although it might appear from an initial review that it is written for the manufacturing or IT industries, in reality the document is adaptable to any industry, including construction.

A construct of PMBOK5 is a graphic depicting the interaction of the Five Project Management Process Groups (Process Groups). See Figure 2. While the Process Groups are depicted as separate and distinct, PMBOK5 provides that all projects are different and the actual interactions among processes could vary greatly. ${ }^{8}$ Moreover, each process group is comprised of numerous processes. For example, the Planning Process Group includes, among other things, estimating costs, scope management, risk management, and procurement management. 


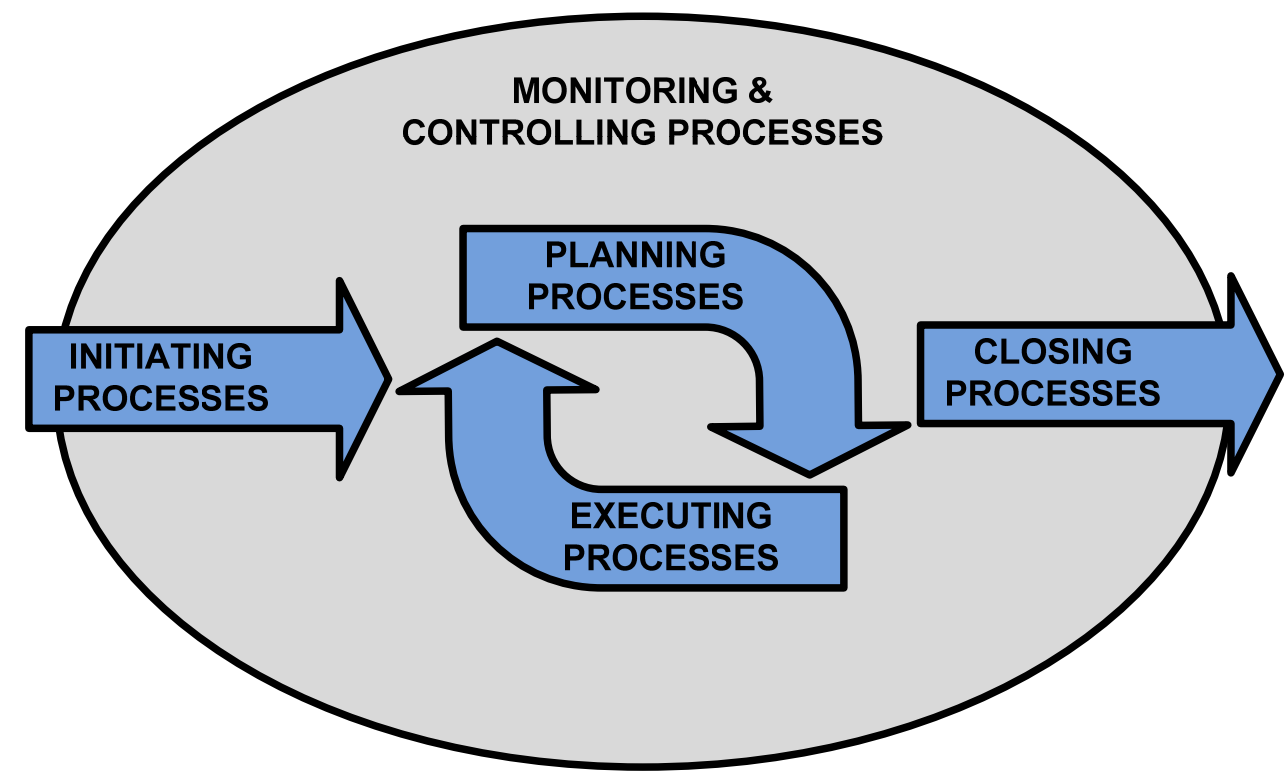

Figure 2: Adapted from the PMBOK5 Project Management Process Groups graphic

To utilize the PMBOK5 for a profession such as civil engineering, or an industry such as construction, interpretation is necessary, and, indeed, expected. The language of PMBOK5 is sufficiently flexible and applicable for use in an engineering design project or a construction project.

Another aspect of the PMBOK5 is that a management team can select which components to employ. For example, it is not usual practice for a civil engineering firm or a construction company, when commencing a project, to create a project charter as set forth in PMBOK5. Ignoring this component likely will not affect the development of a project management plan.

\section{Overview of CE Management}

\section{A. Course Description}

An overview of ECE4243 Civil Engineering Management Practices (CE Management) is a component of the Course Purpose Document ${ }^{9}$ (see Appendix B):

The purpose of ECE4243 is to provide an overview of the concepts and standards of project management practices in the construction industry. The course introduces students to the five project management process groups: initiation, planning, execution, monitoring and controlling, and closing. Students analyze and evaluate various aspects of construction projects and their attendant contract documents within the context of the project management processes, such as scope management, schedule management and risk management.

CE Management, as the name suggests, was originally conceived as a class that focused on the business aspects of engineering, such as staffing, cash flow, etc. Over the years the mission evolved and transformed, however, as the instructor recognized that in a civil engineering 
curriculum where design courses predominate, students needed to develop the ability to apply project management concepts. Moreover, managing projects was more than just an academic exercise; the first post-degree job for a significant number of program graduates was as a project engineer for a construction company, with their job tasks essentially those of an assistant project manager.

But the need for project management skills goes beyond working for a construction company. Civil Engineering Industry Advisory Board members and other industry practitioners consistently advise faculty that students must learn to work in teams, because the industry's move toward more collaborative practices is accelerating and inexorable. Working in teams, whether it is in construction or in one of the design subdisciplines, requires the mastering of project management skills. Irrespective of which civil engineering subdiscipline students will eventually practice in, they will all utilize project management skills.

The main constraint on the CE Management course content derives from the fact that it is the construction engineering component of a civil engineering program. All civil engineering programs are required to provide a broad education, which includes several design subdiscipline courses with attendant laboratory experience. Consequently, the credits available for project management courses are severely limited. While a construction management curriculum may include two project management courses and possibly a separate scheduling course, there are insufficient credits available in a civil engineering curriculum to provide such coverage. Consequently, CE Management is necessarily a survey course; while the content is broad, but the topics are not covered in great depth.

\section{B. CE Management Student Outcomes}

While the content of all advanced civil engineering courses at Lawrence Tech address several student outcomes, there is usually a principal outcome that essentially governs the course content. For example, Hydraulic Engineering addresses outcomes such as natural science, mechanics, and sustainability. However, since Hydraulic Engineering is a design-based course, Outcome 9: Design is the principal outcome.

The principal outcome for CE Management, the one that drives its content is, unsurprisingly, Outcome 13: Project Management. The BOK2 description of this outcome, and the achievement level selected by the Civil Engineering faculty, is "Formulate documents to be included into the project plan.” 10 The description of this outcome for the Civil Engineering program was adapted by the faculty and includes an additional action verb:

Analyze a proposed project and formulate documents for incorporation into the project management plan. 
CE Management addresses several other outcomes, as set forth in Figure 3.

\begin{tabular}{|c|l|}
\hline No. & \multicolumn{1}{|c|}{ Outcome } \\
\hline 10 & Sustainability \\
\hline 11 & $\begin{array}{l}\text { Contemporary issues and historical } \\
\text { Perspectives }\end{array}$ \\
\hline 12 & Risk and uncertainty \\
\hline 13 & Project management \\
\hline 14 & Breadth in civil engineering areas \\
\hline 15 & Technical specialization \\
\hline
\end{tabular}

\begin{tabular}{|c|l|}
\hline No. & \multicolumn{1}{|c|}{ Outcome } \\
\hline 16 & Communication \\
\hline 17 & Public policy \\
\hline 18 & Business and public administration \\
\hline 19 & Globalization \\
\hline 21 & Teamwork \\
\hline
\end{tabular}

Figure 3: BOK2 student outcomes for CE Management

The full descriptions for the student outcomes were developed by faculty and are a product of numerous discussions and iterations (see Appendix A). The final wording is a combination of:

- the language in Appendix I of the Body of Knowledge Outcome Rubric in BOK2, which provides descriptions of the particular outcome for various levels of achievement;

- the discussion of each outcome in Appendix J Explanations of Outcomes in BOK2, which provides a modicum of detail on ways to satisfy the outcome; and

- faculty input based on expertise, research, etc.

As part of the requirements of ABET accreditation, and for continuous improvement of the curriculum, the language of the final student outcomes were reviewed and approved by the Lawrence Tech Civil Engineering Advisory Board.

Assigning outcomes to individual courses is generally within the purview of the course coordinator; i.e., the faculty member who created the course and/or is the primary instructor. Wider discussions, however, were held among faculty to assure that there was sufficient coverage of each outcome throughout the curriculum. For example, Outcome 17: Public Policy is generally covered in the capstone courses. But faculty agreed that additional coverage was required, and CE Management was the course that would most likely contain the content to satisfy Outcome 17.

Faculty interprets most BOK2 outcomes as course-based; that is, they are assigned to address one or more content topics. Outcome 14: Breadth in Civil Engineering Areas (Breadth) and Outcome 15: Technical Specialization (Specialization), however, are analyzed and assigned based on overall curricular requirements:

Outcome 14: Breadth

Analyze and solve well-defined engineering problems in at least four technical areas appropriate to civil engineering.

Outcome 15: Specialization

Apply specialized tools or technologies to solve problems in traditional or emerging specialized technical areas of civil engineering. 
To attain accreditation, a civil engineering program must "apply knowledge of four technical areas appropriate to civil engineering ${ }^{11}$," a reference to the traditional civil engineering subdisciplines: structural engineering, transportation engineering, geotechnical engineering, water resources engineering, environmental engineering, construction engineering, and surveying. Based on a combination of required and elective courses, faculty has identified all the subdisciplines except surveying as covered technical areas.

CE Management is considered a top tier course in the curriculum, i.e., one that satisfies the construction engineering subdiscipline technical area. Consequently, as interpreted by faculty, the course must satisfy the Breadth and Specialization outcomes.

\section{Course Execution}

Like most engineering courses, CE Management was presented in the traditional manner: inclass lectures buttressed with homework assignments. With the availability of Blackboard, the online course management system, and Panopto, a lecture capture software, a significant portion of content is now delivered employing a hybrid model. Many of the course topics, or modules, are presented in the inverted or flipped fashion, utilizing online screencasting in conjunction with an in-class practicum that includes a realistic scenario designed to elicit critical thinking and application of concepts.

Problem-based learning (PBL) and active/collaborative learning (ACL) techniques, both formal and informal, are utilized with the practicum. Figure 4 depicts the flow of course content utilizing an inverted technique based on an informal PBL/ACL; the in-class portion of the exercise, the practicum review and resultant student presentations or "report out", occurs in a single class period.

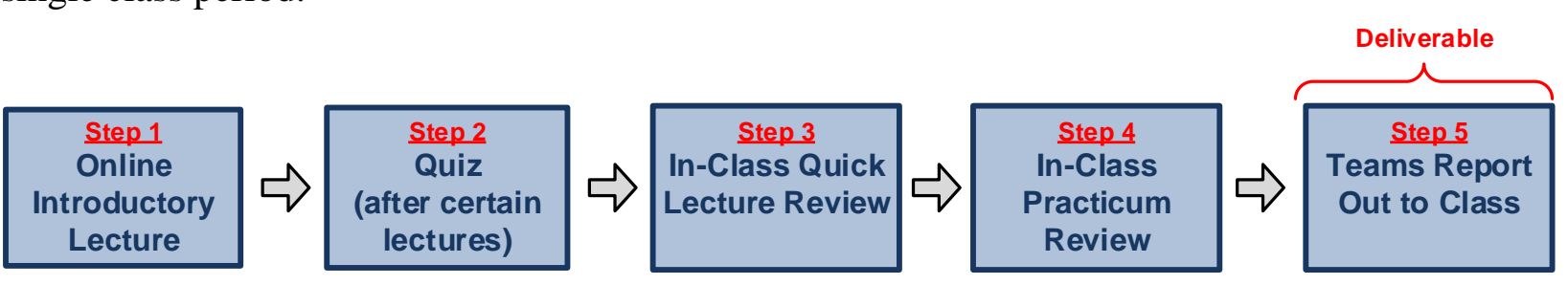

Figure 4: Flowchart for an informal PBL/ACL practicum

The instructor uses the practicum review step to visit individual teams and answer questions, and to also ask probing questions for their consideration as they discuss the scenario. The report out is a further opportunity for the instructor to reinforce the salient module learning elements.

Figure 5 depicts the flow of the course content based on a formal PBL/ACL practicum. The students initially meet in the classroom, but must also schedule meetings outside of class to complete the deliverables. Assignments usually require students to conduct a more thorough and formal oral presentation, as well as submitting a written report. 


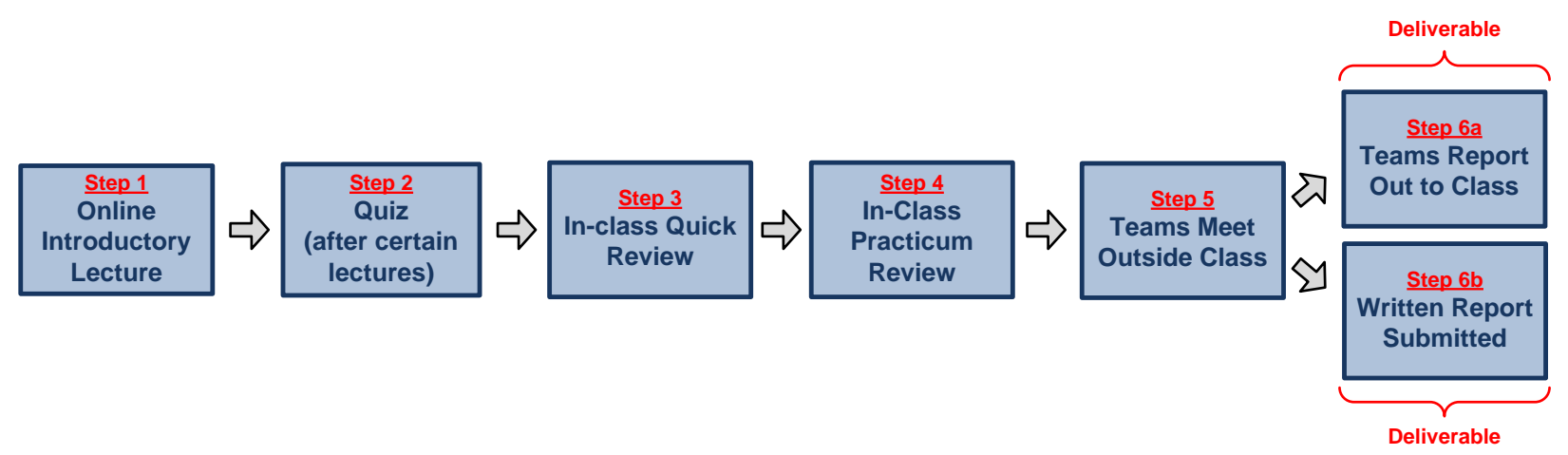

Figure 5: Flowchart for a formal PBL/ACL practicum

\section{III.Melding the BOK2 and the PMBOK5}

\section{A. Developing the BOK2/PMBOK5 Matrix}

As previously discussed, because of the lack of available credits in the civil engineering curriculum, CE Management is necessarily a survey course, wherein covering relatively few topics in depth is sacrificed for covering a wide range of project management topics. Which topics the instructor should address is another aspect of the course that has evolved over the years. Some subjects were disregarded because they were addressed in other courses, such as safety and OSHA requirements. Other subjects were considered too esoteric and not sufficiently important to undergraduate education to include, such as alternative dispute resolution requirements and techniques.

The adoption of the BOK2 student outcomes, and the commitment to infuse CE Management with project management concepts as set forth in the PMBOK5, provide a foundation for course topics. Both the BOK2 and the PMBOK5 are not prescriptive; rather, they are general standards that allow the instructor sufficient flexibility to research and select topics appropriate to the course mission. The instructor is free to choose topics from an infinite number of sources, including their own experience and research, advisory board suggestions, adjunct input, etc.

An initial framework for the course was the creation of a relationship matrix that provides an overview as to how the two standards correlated; where there are similarities, where interpretations are required, etc. (see Figure 6). 


\begin{tabular}{|c|c|c|c|c|c|c|c|c|c|c|}
\hline \multirow[b]{2}{*}{$\begin{array}{c}\text { PMBOK5 } \\
\text { PMT MANAGEMENT } \\
\text { PROJECT } \\
\text { PROCESSES }\end{array}$} & \multicolumn{10}{|c|}{ BOK2 STUDENT OUTCOMES/COVERAGE } \\
\hline & 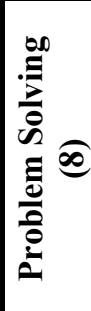 & 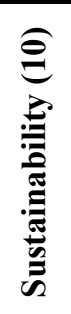 & 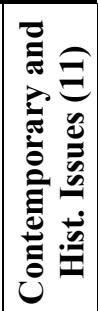 & 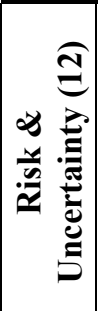 & 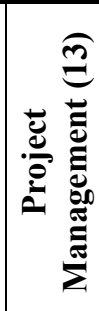 & : & 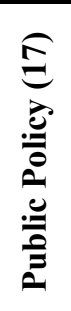 & 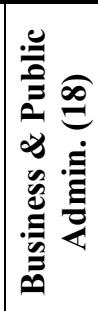 & 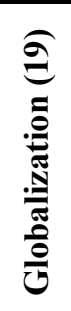 & 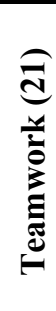 \\
\hline Project Management Process Groups & & & $\sqrt{ }$ & & $\sqrt{ }$ & & & & & \\
\hline Develop Project Management Plan & $\sqrt{ }$ & & $\sqrt{ }$ & & $\sqrt{ }$ & & & & $\sqrt{ }$ & \\
\hline Direct and Manage Project Work & $\sqrt{ }$ & & $\sqrt{ }$ & & $\sqrt{ }$ & & & & & \\
\hline $\begin{array}{l}\text { Monitor and Control Project Work } \\
\text { [Quality Management] }\end{array}$ & $\sqrt{ }$ & & $\sqrt{ }$ & & $\sqrt{ }$ & & $\sqrt{ }$ & $\sqrt{ }$ & & \\
\hline $\begin{array}{l}\text { Perform Integrated Change Control } \\
\text { [Change Management] }\end{array}$ & $\sqrt{ }$ & & $\sqrt{ }$ & $\sqrt{ }$ & $\sqrt{ }$ & & & & & \\
\hline Close Project or Phase & $\sqrt{ }$ & & $\sqrt{ }$ & & $\sqrt{ }$ & & & & & \\
\hline Scope Management & $\sqrt{ }$ & $\sqrt{ }$ & $\sqrt{ }$ & $\sqrt{ }$ & $\sqrt{ }$ & & & & & \\
\hline $\begin{array}{l}\text { Time Management } \\
\text { [Schedule Management] }\end{array}$ & $\sqrt{ }$ & & $\sqrt{ }$ & $\sqrt{ }$ & $\sqrt{ }$ & & & & & \\
\hline Cost Management & $\sqrt{ }$ & & $\sqrt{ }$ & $\sqrt{ }$ & $\sqrt{ }$ & & & & & \\
\hline Quality Management & $\sqrt{ }$ & & $\sqrt{ }$ & & $\sqrt{ }$ & & & & & \\
\hline Communications Management & $\sqrt{ }$ & & $\sqrt{ }$ & & $\sqrt{ }$ & $\sqrt{ }$ & & & & $\sqrt{ }$ \\
\hline Risk Management & $\sqrt{ }$ & & $\sqrt{ }$ & $\sqrt{ }$ & $\sqrt{ }$ & & & & & \\
\hline Procurement Management & $\sqrt{ }$ & & $\sqrt{ }$ & & $\sqrt{ }$ & & $\sqrt{ }$ & $\sqrt{ }$ & & \\
\hline Stakeholder Management & $\sqrt{ }$ & & $\sqrt{ }$ & & $\sqrt{ }$ & & $\sqrt{ }$ & $\sqrt{ }$ & & \\
\hline
\end{tabular}

Figure 6: Project management processes/student outcomes relationship matrix

A couple of clarifications are necessary to assist with understanding how both standards are adapted for use in CE Management. First, in section II B, Outcome 14: Breadth and Outcome 15: Specialization were identified as student outcomes that are considered curricular-wide, rather than topic- or course-specific. Consequently, they do not have specific PMBOK5 correlate processes and were omitted from the matrix. Specialization, however, does play an important role in accreditation and is an integral outcome because, along with Breadth, it identifies CE Management as a top tier course and one of the civil engineering subdisciplines needed for accreditation. As previously provided, the description of Outcome 15: Specialization for the level of achievement selected by faculty, is as follows:

Apply specialized tools or technologies to solve problems in traditional or emerging specialized technical areas of civil engineering.

The ability to satisfy Specialization is conditioned on the use of "specialized tools or technologies" in the execution of the course, a phrase which the BOK2 does not define or clarify. Thus, it is the instructor's responsibility to make the determination as to which tool is used. For Structural Steel Design, another top tier course, the instructor may consider the AISC Steel Construction Manual as the specialized tool that satisfies Outcome 15. For CE Management, the instructor determined that the PMBOK5 serves as this specialized tool. 
Another clarification required for the BOK2/PMBOK5 discussion involves the term "Knowledge Areas" as employed by the PMBOK5. All the project management processes are grouped into ten Knowledge Areas, including Project Scope Management and Project Quality Management. ${ }^{12}$ For a survey course like CE Management, where there are more potential topics than available time to present them, the instructor must avoid additional layers of complexity whenever possible. Requiring students to understand the usage of Knowledge Areas, when the term arguably does not provide clarification, is unhelpful and unnecessary.

In the matrix, some of the BOK2 Outcomes are sufficiently general such that they are applicable to all the processes. For example, Outcome 11: Contemporary Issues was addressed for virtually all processes through the use of articles from periodicals such as ENR and Civil Engineering Magazine. At the start of many class periods the instructor allocates a few minutes to discuss an article that covers contemporary project management issues.

A major revision from the previous edition to PMBOK5 is the inclusion of Chapter 13 Project Stakeholder Management, which demonstrates how the use of PMBOK5 allows for instructor interpretation to address a particular topic. In CE Management, discussing the initiation of an infrastructure project provides an opportunity to consider the concept of context sensitive solutions, a methodology which considers the input from stakeholders, especially taxpayers and the general public, before final design and construction decisions are made. PMBOK5 provides students with general direction as to managing this type of stakeholder engagement, while addressing various outcomes, including Public Policy and Business and Public Administration.

\section{B. Developing Course Objectives}

Course objectives are the backbone of a course, and serve many purposes, such as:

- Providing students with the topics the course covers

- Allowing the instructor to focus on salient topics

- Providing a basis for outcome assessment

Because the BOK2 and the PMBOK5 play such prominent roles in the content and execution of CE Management, it was necessary to include language from both standards in the course objectives. Amalgamating two standards so they are part of the framework of the course also demonstrates that CE Management is utilizing PMBOK5 as a specialized project management tool, in accordance with Outcome 15: Technical Specialization. Similar to the other courses in the curriculum, the CE Management course objectives are a component of a Course Purpose Document, which is provided all students at the start of the term (see Appendix B).

There is a distinction between certain types of objectives that is similar to the distinction between course-based outcomes and curriculum-based outcomes. Some objectives are written in general language to address the entire course content, while others are specifically tailored to cover only one or two topics. 
The first CE Management course objective is characterized as general and serves as the foundation for all the objectives:

Utilizing the Project Management Body of Knowledge $5^{\text {th }}$ Edition, an industry standard for project management concepts, discuss and analyze contemporary and historical issues regarding the initiating, planning, executing, monitoring and controlling, and closing of a project.

Several attributes of the objective are worth noting:

- PMBOK5 is specifically referenced, leaving no question as to what specialized tool is utilized for satisfying Outcome 15

- Outcome 11: Contemporary Issues is specifically referenced

- The five project management process groups are specifically referenced, as they are in Appendix $\mathrm{J}$ of the $\mathrm{BOK} 2^{13}$

Course objective \#7 is characterized as specific, not only for a topic, but also for coverage in both standards:

Describe the risk management process and qualitatively evaluate a project for potential risks and risk responses.

Attributes worth noting:

- The processes involved in project risk management are discussed in-depth in PMBOK5

- The inclusion of Outcome 12: Risk and Uncertainty in the BOK2 is an acknowledgement of the importance of risk assessment

Course objective \#10 is also characterized as specific:

Explain aspects of closing a project, such as procedures for commissioning various building components, and analyzing the project documents to determine whether substantial and final completion were attained.

Attributes worth noting:

- Closing a project is treated as a specific process in PMBOK5

- Commissioning is a topic that is not specifically addressed in either standard but was identified as an important concept that is growing in usage in the construction industry

- Project documents are referenced; standard industry contract documents are employed throughout the course, including those promulgated by the Engineers Joint Contract Documents Committee and the ConsensusDOCS.

\section{Developing and Executing Learning Modules}

When PMBOK5 concepts were infused into the course content of CE Management, the framework for the learning modules were the five project management process groups. The process groups graphic, referenced in Figure 2, serves two main functions: 1) the graphic is the course lynchpin because it depicts the flow of the process groups in the delivery of a project; and 2) the graphic also provides a simple roadmap for students so they can visualize where a particular learning module fits into the context of a project. At the commencement of each learning module, the graphic is referenced to place the module into context. 
For example, an important concept in construction project management is how to contractually deliver a project. Analyzing and selecting the appropriate project delivery method (PDM) is a component of procurement management, which is considered a component of the planning process group, and, depending on the project, the initiating process group. Figure 7 depicts the flow of standards covered through assessment using the course topic of project delivery methods, which addresses Course Objective \#6.

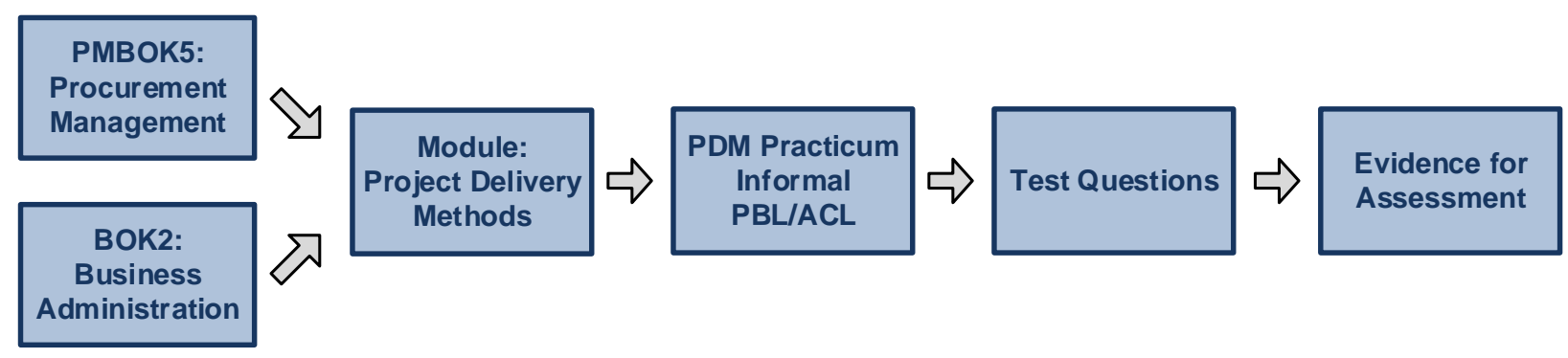

Figure 7: Project delivery methods learning module flowchart

The PDM practicum is a team-based informal PBL/ACL exercise with an oral report out. The assessment is based on test questions in the mid-term and final exams.

Course Objective \#5 addresses developing a schedule network diagram. Figure 8 provides the flowchart for the learning module.

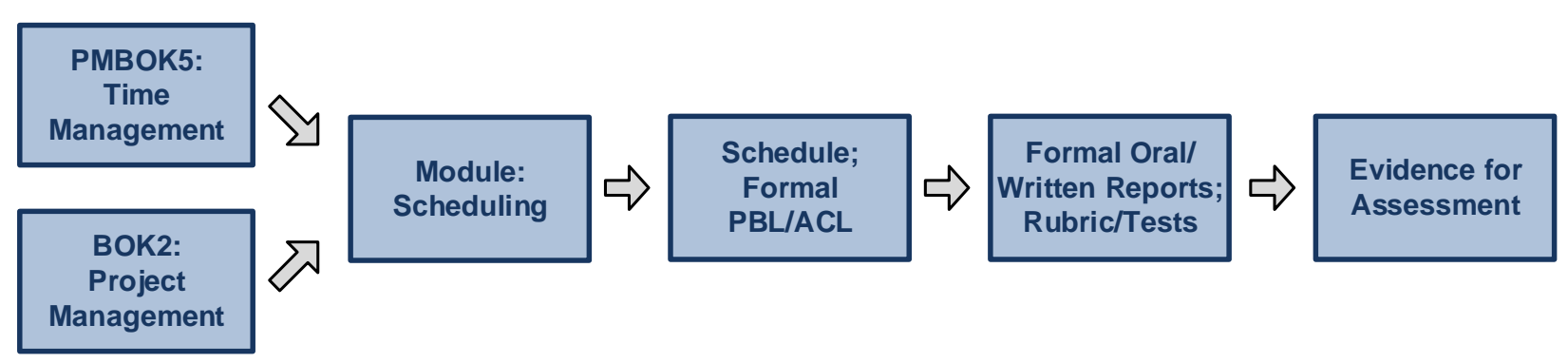

Figure 8: Project schedule learning module flowchart

Assessment of informal PBL/ACL activities is a combination of the instructor's observations and responses to test questions. For formal PBL/ACL activities, rubrics were developed as an assessment tool. For example, for the scheduling learning module students are required to generate a network diagram. A rubric was developed to grade the assignment, but also for the students to use as a guide as to the instructor's expectations (see Appendix C).

The rubric dimensions are grouped in three sections: writing, technical and oral. The criteria for the various writing and oral dimensions were standardized so they could be used in any of the course rubrics. A technical section is included in each rubric, with dimension designations and criteria language specific to that particular assignment. 
The scheduling assignment rubric in Appendix $\mathrm{C}$ is demonstrative as to how PMBOK5 terminology and concepts are infused into the CE Management course. The dimension designations, Decomposition, Network Logic/Constraints and Activity Scope Narrative are terms adapted directly from the Project Time Management chapter. Similarly, the criteria descriptive language, as much as possible, employs terminology from the chapter.

\section{Final Considerations}

The BOK2 and PMBOK5 work well together as the foundational documents with which to build a project management-based course within a civil engineering curriculum. The BOK2 provides the framework for the outcomes the industry expects undergraduates to attain, and also the basis for academic assessment. On the other hand, the PMBOK5 provides structure to the course, allowing the instructor to choose from a wide array of project management concepts to apply to course learning modules. It is worth noting again that the BOK2 specifically references a version of PMBOK5, thus providing legitimacy to utilizing the standard.

The instructor must be judicious when assigning reading in the PMBOK5, which is chock-full of terms and phrases, and could result in students getting "lost in the weeds." Indeed, readers can spend a great amount of time looking up definitions of terms which are not germane to the learning module. Requiring students to memorize terms that are not particularly useful serves as a barrier to deeper learning of the more important concepts. For example, while terms such as “organizational process assets” or “contingent response strategies” are important to the project management professional, they are too esoteric and tangential for a student taking a project management survey course.

Although it initially requires significant time and thought, instructors should sculpt the reading assignments so all unnecessary terms and concepts are rooted out. Moreover, PMBOK5 works especially well when a particular concept is clearly placed in context of the applicable learning module. 


\section{Appendix A \\ Department of Civil Engineering Student Outcomes}

\begin{tabular}{|c|c|}
\hline $\begin{array}{l}\text { Outcome } \\
\text { Number } \\
\text { and Title }\end{array}$ & $\begin{array}{l}\text { To graduate with a B.S. Degree in Civil Engineering from Lawrence } \\
\text { Technological University and enter the practice of civil engineering, the } \\
\text { student must demonstrate competence in each of } 24 \text { Student Outcomes. }\end{array}$ \\
\hline \multicolumn{2}{|r|}{ Foundational Outcomes } \\
\hline $\begin{array}{c}1 \\
\text { Mathematics }\end{array}$ & $\begin{array}{l}\text { Solve problems in mathematics through differential equations and apply this } \\
\text { knowledge to the solution of engineering problems. }\end{array}$ \\
\hline $\begin{array}{c}2 \\
\text { Natural Sciences }\end{array}$ & $\begin{array}{l}\text { Solve problems in calculus-based physics, chemistry and geology, and } \\
\text { apply this knowledge to the solution of engineering problems. }\end{array}$ \\
\hline $\begin{array}{c}3 \\
\text { Humanities }\end{array}$ & $\begin{array}{l}\text { Demonstrate the importance of the humanities in the professional practice } \\
\text { of engineering. }\end{array}$ \\
\hline $\begin{array}{c}4 \\
\text { Social Sciences }\end{array}$ & $\begin{array}{c}\text { Demonstrate the incorporation of social sciences knowledge into the } \\
\text { professional practice of engineering. }\end{array}$ \\
\hline \multicolumn{2}{|r|}{ Technical Outcomes } \\
\hline $\begin{array}{l}5 \\
\text { Materials } \\
\text { Science }\end{array}$ & $\begin{array}{c}\text { Use knowledge of materials science to solve problems appropriate to civil } \\
\text { engineering. }\end{array}$ \\
\hline $\begin{array}{c}6 \\
\text { Mechanics }\end{array}$ & Analyze and solve problems in solid and fluid mechanics. \\
\hline $\begin{array}{c}7 \\
\text { Experiments }\end{array}$ & $\begin{array}{l}\text { Specify and design an experiment to meet a specified need; conduct the } \\
\text { experiment and analyze, interpret and explain the resulting data. }\end{array}$ \\
\hline $\begin{array}{l}\text { 8 } \\
\text { Problem } \\
\text { Recognition and } \\
\text { Solving } \\
\end{array}$ & $\begin{array}{l}\text { Develop problem statements and solve both well-defined and open-ended } \\
\text { civil engineering problems by selecting and applying appropriate } \\
\text { techniques and tools. }\end{array}$ \\
\hline $\begin{array}{c}9 \\
\text { Design }\end{array}$ & $\begin{array}{c}\text { Design a system or process to meet desired needs within such realistic } \\
\text { constraints as economic, environmental, social, political, ethical, health and } \\
\text { safety, constructability and sustainability. }\end{array}$ \\
\hline $\begin{array}{c}10 \\
\text { Sustainability }\end{array}$ & $\begin{array}{c}\text { Apply the principles of sustainability to the design of traditional and } \\
\text { emergent engineering systems and explain how civil engineers should strive } \\
\text { to comply with the principles of sustainable development in the } \\
\text { performance of their professional duties. }\end{array}$ \\
\hline $\begin{array}{c}11 \\
\text { Contemporary } \\
\text { Issues and } \\
\text { Historical } \\
\text { Perspectives } \\
\end{array}$ & $\begin{array}{c}\text { Explain the impact of historical and contemporary issues on the } \\
\text { identification and formulation of solutions to engineering problems, and } \\
\text { explain the impact of engineering solutions on the economy, environment, } \\
\text { political landscape and society. }\end{array}$ \\
\hline $\begin{array}{c}12 \\
\text { Risk and } \\
\text { Uncertainty }\end{array}$ & $\begin{array}{c}\text { Apply the principles of probability and statistics and solve problems } \\
\text { containing uncertainty. }\end{array}$ \\
\hline $\begin{array}{c}13 \\
\text { Project } \\
\text { Management }\end{array}$ & $\begin{array}{c}\text { Analyze a proposed project and formulate documents for incorporation into } \\
\text { the project management plan. }\end{array}$ \\
\hline
\end{tabular}




\begin{tabular}{|c|c|}
\hline $\begin{array}{l}14 \\
\text { Breadth in Civil } \\
\text { Engineering } \\
\text { Areas }\end{array}$ & $\begin{array}{l}\text { Analyze and solve well-defined engineering problems in at least four } \\
\text { technical areas appropriate to civil engineering. }\end{array}$ \\
\hline \multirow[t]{2}{*}{$\begin{array}{c}15 \\
\text { Technical } \\
\text { Specialization } \\
\end{array}$} & $\begin{array}{l}\text { Apply specialized tools or technologies to solve problems in traditional or } \\
\text { emerging specialized technical areas of civil engineering. }\end{array}$ \\
\hline & Professional Outcomes \\
\hline $\begin{array}{c}16 \\
\text { Communication } \\
\end{array}$ & $\begin{array}{l}\text { Plan, compose and integrate the verbal, written, virtual and graphical } \\
\text { communication of a project to technical and non-technical audiences. }\end{array}$ \\
\hline $\begin{array}{c}17 \\
\text { Public Policy }\end{array}$ & Discuss and explain key concepts and processes involved in public policy. \\
\hline $\begin{array}{c}18 \\
\text { Business } \\
\text { and Public } \\
\text { Administration }\end{array}$ & $\begin{array}{c}\text { Explain key concepts and processes used in business and public } \\
\text { administration. }\end{array}$ \\
\hline $\begin{array}{c}19 \\
\text { Globalization }\end{array}$ & $\begin{array}{c}\text { Explain global issues related to professional practice, infrastructure, } \\
\text { environment and service populations as such issues arise across cultures and } \\
\text { countries. }\end{array}$ \\
\hline $\begin{array}{c}20 \\
\text { Leadership }\end{array}$ & $\begin{array}{l}\text { Explain leadership principles and attitudes and apply those principles and } \\
\text { attitudes when making decisions and directing the efforts of a small group. }\end{array}$ \\
\hline $\begin{array}{c}21 \\
\text { Teamwork } \\
\end{array}$ & $\begin{array}{l}\text { Function effectively as a member of an intra-disciplinary team and } \\
\text { evaluate the performance of the team and individual team members. }\end{array}$ \\
\hline $\begin{array}{c}22 \\
\text { Attitudes }\end{array}$ & $\begin{array}{c}\text { Explain attitudes supportive of the professional practice of civil } \\
\text { engineering. }\end{array}$ \\
\hline $\begin{array}{l}23 \\
\text { Lifelong } \\
\text { Learning }\end{array}$ & $\begin{array}{c}\text { Demonstrate the ability for self-directed learning and identify additional } \\
\text { knowledge, skills and attitudes appropriate for continued professional } \\
\text { practice. }\end{array}$ \\
\hline $\begin{array}{l}24 \\
\text { Professional and } \\
\text { Ethical } \\
\text { Responsibility }\end{array}$ & $\begin{array}{l}\text { Explain the many aspects of professionalism and what it means to be a } \\
\text { member of the civil engineering profession; analyze a situation involving } \\
\text { multiple conflicting professional and ethical interests to determine an } \\
\text { appropriate course of action. }\end{array}$ \\
\hline
\end{tabular}




\begin{tabular}{|c|c|c|}
\hline APPENDIX B & \multicolumn{3}{|c|}{$\begin{array}{c}\text { LAWRENCE TECHNOLOGICAL UNIVERSITY } \\
\text { DEPARTMENT OF CIVIL ENGINEERING }\end{array}$} \\
\hline \multicolumn{4}{|c|}{ Course Purpose Document } \\
\hline ECE4243 & \multicolumn{3}{c|}{ CE Management Practices } \\
\hline Coordinator/Preparer: J. Tocco & Effective Date: January 1, 2013 & Required Course \\
\hline
\end{tabular}

\section{Catalog Description}

Prerequisite: Senior Standing. Overview of business and management practices applied to organizations involved in civil engineering, including consulting design firms, construction contractors, private owners and government agencies. Budgeting, project programming, revenue sources and company profitability. Organizational structures and effective team-building methods. Oral and written communication skills are developed. Lecture: three hours, credit: three hours.

\section{Textbooks and other required material}

- Project Management Body of Knowledge, Fifth Edition; Project Management Institute (reference only)

- Various standard industry contract documents

\section{Course Objectives}

1. Utilizing the Project Management Body of Knowledge $5^{\text {th }}$ Edition, an industry standard for project management concepts, discuss and analyze contemporary and historical issues regarding the initiating, planning, executing, monitoring and controlling, and closing of a project.

2. Review and evaluate various standard industry contract documents to determine the responsibility and authority for project managers representing various primary stakeholders, such as governmental agencies, design firms and constructors.

3. Explain aspects of scope management, such as sustainability and site management, and how various stakeholders influence the final scope of a project.

4. Explain aspects time management and communication management, such as schedule requirements and the multidiscipline collaboration required for various forms of integrated project delivery.

5. Analyze a proposed project, compose an activity list, and develop a schedule network diagram.

6. Analyze a proposed project and create components of a procurement management plan by identifying the appropriate contractual structures and the most efficient project delivery methods.

7. Describe the risk management process and qualitatively evaluate a project for potential risks and risk responses.

8. Analyze a project site utilizing Lean construction concepts, identify components of and generate a logistics plan.

9. Explain components of integration management, including change control, monitoring and controlling, and managing the work.

10. Explain aspects of closing a project, such as procedures for commissioning various building components, and analyzing the project documents to determine whether substantial and final completion were attained. 
11. Discuss the purpose for and the components of an asset management program, and generate the framework for an asset management plan.

12. Individually and in teams, analyze a proposed project with multiple timelines and logistics requirements and generate salient portions of a project management plan, thus mastering the construction engineering component of the technical breadth and specialization required to function as a competent civil engineer.

13. Analyze project management issues and effectively communicate observations and solutions orally, and by composing written and graphical documents in a clear, concise and professional manner.

\section{Class Schedule}

Two sessions per week, one hour and fifteen minutes per session

\section{Course Purpose}

The purpose of ECE4243 is to provide an overview of the concepts and standards of project management practices in the construction industry. The course introduces students to the five project management process groups: initiation, planning, execution, monitoring and controlling, and closing. Students analyze and evaluate various aspects of construction projects and their attendant contract documents within the context of the project management processes, such as scope management, schedule management and risk management.

\section{Course Objectives/Student Outcomes Relationship Matrix}

\begin{tabular}{|c|c|c|c|c|c|c|c|c|c|c|c|c|}
\hline \multirow[b]{2}{*}{$\begin{array}{c}\text { COURSE } \\
\text { OBJECTIVES }\end{array}$} & \multicolumn{12}{|c|}{ STUDENT OUTCOMES/LEVELS } \\
\hline & 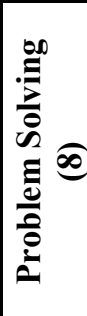 & 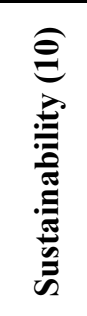 & 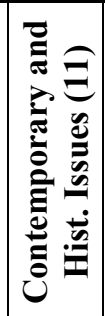 & 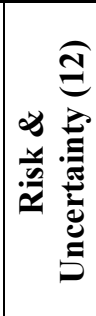 & 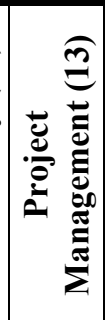 & 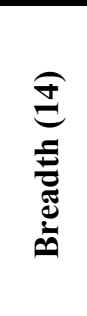 & 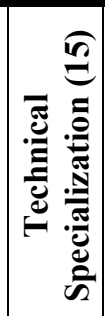 & 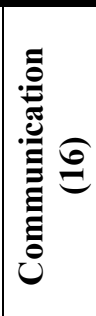 & 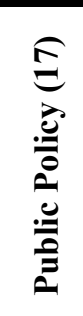 & 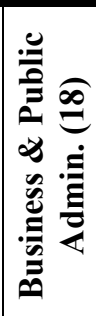 & 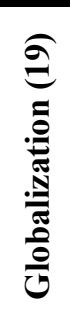 & 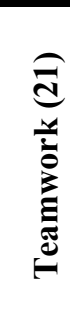 \\
\hline$\overline{1}$ & & & 3 & & 2 & & & & & & 2 & \\
\hline 2 & & & 2 & & 3 & & & & & & & \\
\hline 3 & & 2 & & & 3 & & & & & & & \\
\hline 4 & & & 3 & & 3 & & & & & & & \\
\hline 5 & 4 & & & & 4 & & & & & & & \\
\hline 6 & 4 & & 3 & & 4 & & & & 2 & 2 & & \\
\hline 7 & 4 & & 3 & 2 & 4 & & & & 2 & 2 & & \\
\hline 8 & 4 & & 3 & & 4 & & & & & & & \\
\hline 9 & & & 3 & & 4 & & & & & 2 & & \\
\hline 10 & & & & & 3 & & & & & & & \\
\hline 11 & 2 & 2 & 3 & 2 & 3 & & & & 2 & 2 & & \\
\hline 12 & & & & & 4 & 4 & 3 & & & & & 3 \\
\hline 13 & & & & & & & & 4 & & & & \\
\hline $\begin{array}{c}\text { Highest Level } \\
\text { of Cognitive } \\
\text { Achievement }\end{array}$ & L4 & L2 & $\mathbf{L 3}$ & $\mathbf{L 2}$ & L4 & L4 & $\mathbf{L 3}$ & L4 & L2 & $\mathbf{L 2}$ & L2 & L3 \\
\hline
\end{tabular}




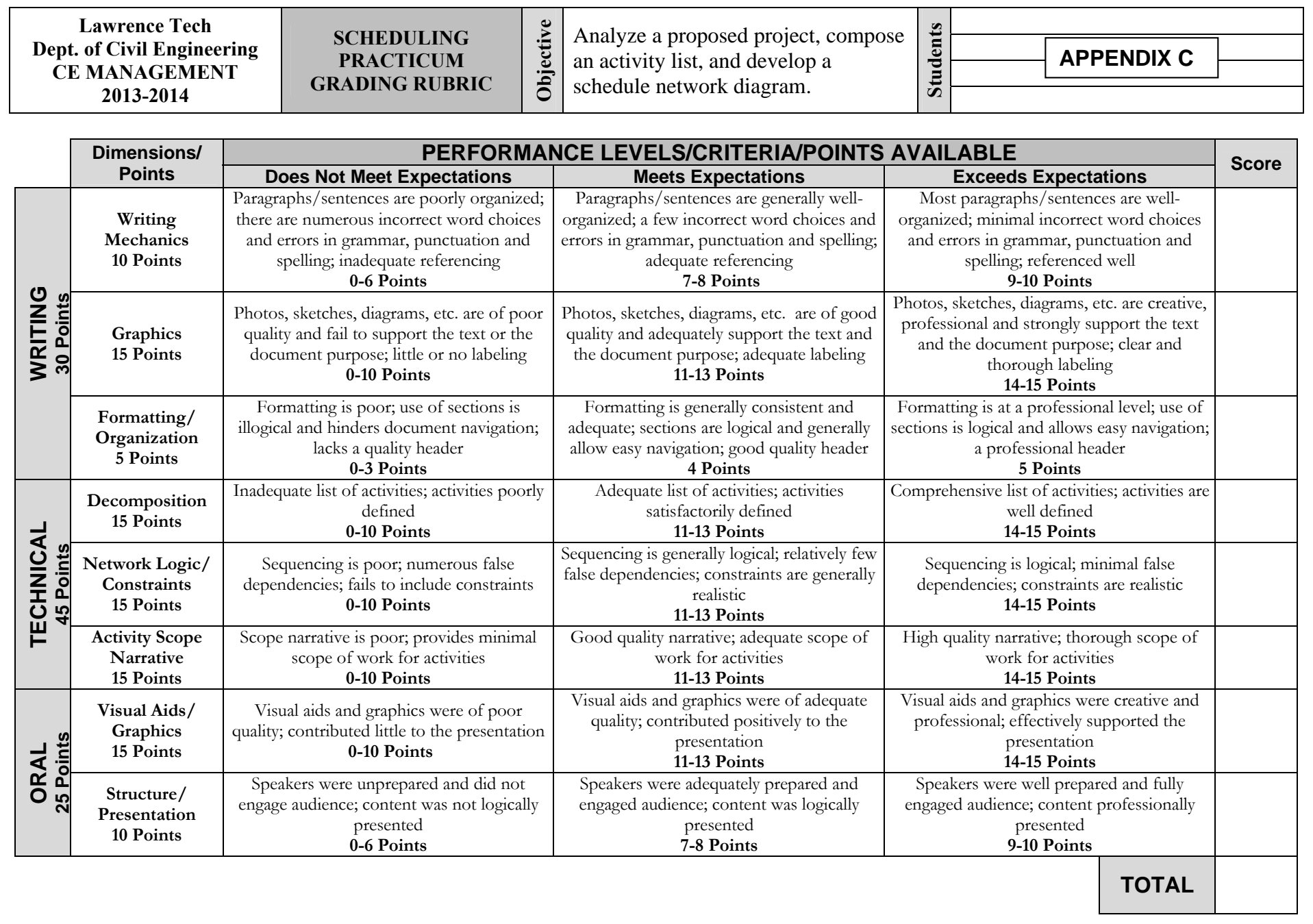




\section{Endnotes}

1 "Academic Prerequisites for Licensure and Professional Practice, Policy Statement 465", American Society of Engineers, http://www.asce.org/pressroom/news/policy_details.cfm?hdlid=15

2 "The Vision for Civil Engineering in 2025", American Society of Engineers, http://www.asce.org/uploadedFiles/Vision_2025_-_New/TheVisionforCivilEngineeringin2025_ASCE.pdf

3 "Civil Engineering Body of Knowledge for the $21^{\text {st }}$ Century, Preparing the Civil Engineer for the Future, Second Edition", 2008, http://www.asce.org/uploadedFiles/Leadership_Training_-

_New/BOK2E_\%28ASCE_2008\%29_ebook.pdf

${ }^{\overline{4}}$ ABET Criteria for Accrediting Engineering Programs, 2013-

2014http://www.abet.org/DisplayTemplates/DocsHandbook.aspx?id=3149

${ }^{5}$ ABET Criteria for Accrediting Engineering Programs, 2013-2014,

http://www.abet.org/uploadedFiles/Accreditation/Accreditation_Step_by_Step/Accreditation_Documents/Curren t/2013_-_2014/eac-criteria-2013-2014.pdf

${ }^{6}$ Project Management Institute, http://www.pmi.org

7 "A Guide to the Project Management Body of Knowledge, Fifth Edition", Project Management Institute, 2013

8 "A Guide to the Project Management Body of Knowledge, Fifth Edition", Project Management Institute, 2013, page 50.

${ }^{9}$ In preparation for the 2010 ABET accreditation evaluation, the Department created CPDs for all the courses to serve as "ABET syllabi." After a successful re-accreditation, faculty agreed that the Department would continue to use CPDs as the basis for curriculum quality control.

10 "Civil Engineering Body of Knowledge for the $21^{\text {st }}$ Century, Preparing the Civil Engineer for the Future, Second Edition", 2008, http://www.asce.org/uploadedFiles/Leadership_Training_-

_New/BOK2E_\%28ASCE_2008\%29_ebook.pdf, page 109.

${ }^{11}$ ABET Program Criteria for Civil and Similarly Named Engineering Programs http://www.abet.org/DisplayTemplates/DocsHandbook.aspx?id=3149

12 "A Guide to the Project Management Body of Knowledge Fifth Edition", Project Management Institute, 2013, Page 60

13 "A Guide to the Project Management Body of Knowledge, Fifth Edition", Project Management Institute, 2013, page 134. 